\title{
CLINICAL TRIALS WITHATRAUMATIC RESTORATIVE TREATMENT (ART) IN DECIDUOS AND PERMANENT TEETH
}

\author{
ESTUDOS CLINICOS UTILIZANDO O TRATAMENTO RESTAURADOR ATRAUMÁTICO \\ (TRA) EM DENTES DECÍDUOS E PERMANENTES
}

\section{Eduardo BRESCIANI}

DDS, MSc, Graduate student, Department of Operative Dentistry Endodontology and Dental Materials, Bauru Dental School, University of São Paulo, Brazil

Corresponding address: Eduardo Bresciani - Faculdade de Odontologia de Bauru - Universidade de São Paulo - Departamento de Dentistica, Endodontia e Materiais Dentários - Al. Dr. Octavio Pinheiro Brisola 9-75 - Cep.: 17012-901, Bauru - São Paulo

Tel / FAX: + 551432358325 - e:mail: edubresc@usp.br

\begin{abstract}
$T$

1 his paper presents a review of the literature on clinical trials with Atraumatic Restorative Treatment. The available scientific literature is encouraging in terms of management of dental caries by this approach, especially for one-surface lesions. The steps of ART are described and the crucial points highlighted. The incorporation of ART into primary health care services, as Family Health Program - PSF, was considered.

Uniterms: Atraumatic Restorative Treatment; Clinical trials, failures; Health care services.
\end{abstract}

\begin{abstract}
RESUMO
$E$ ste artigo apresenta uma revisão da literatura relacionada a estudos clínicos utilizando o tratamento restaurador atraumático (ART). A literatura científica disponível mostra-se encorajadoura em termos de controle da doença cárie através desta abordagem, especialmente em cavidades de uma superfície. Os passos clínicos da técnica são descritos e pontos de crucial importância enfatizados. A incorporação do tratamento restaurador atraumático em serviços de atenção básica à saúde , como o Programa de Saúde da Família, é considerada.

Unitermos: Tratamento Restaurador Atraumático; Estudos clínicos, falhas; Programa de saúde da família.
\end{abstract}

\section{INTRODUCTION}

The ART was developed in Tanzania in mid-1980s as part of a community-based primary oral health program ${ }^{6}$. The ART approach is based on minimal intervention and maximal prevention retaining sound tooth tissues. The technique consists of caries removal using hand instruments only, followed by restoration of the cavity with an adhesive filling material, such as glass-ionomer cement (GIC).

In many countries, the caries process frequently progresses beyond the reversible stage and many people believe that loss of teeth is part of life. The main method of treating dental caries is extraction. The need to develop a new approach to oral care for use in economically less developed regions was reinforced by the World Health Organization (WHO). In 1994, during the annual meeting of IADR $^{165,156}$, the WHO recognized, endorsed and promotes the technique dissemination allover the world ${ }^{39,40}$.
The early results, using conventional glass ionomer cements, were published in literature between 1994 and 1996. The results were lower than conventional treatment but seemed promising to the technique ${ }^{7,10,21,31}$. The improvement of the mechanical and setting properties of the conventional glass ionomer cements ${ }^{13}$ yelded higher survivals rates in later than in earlier ART studies $5,8,14,20,35$.

Although all improvements, the ART approach still faces some resistance among dentists. This resistance occurs mainly due to lack of knowledge about the technique and about the concept of minimal intervention.

Observing this background, the aim of this paper is to describe the technique and its scientific support. The results published in the international scientific literature will be discussed and compared with the results of the studies performed at Bauru Dental School. 


\section{Minimal Intervention - MI}

The concept of minimal intervention (MI) is basically to save tooth structure that can be healed. As described by Fusayama in $1979^{12}$, carious tissue can be divided into two layers. The first one named infected dentin is the outer layer and consists in the smoothest area, with denatured collagen and containing $10^{8}$ photolytic bacteria per gram of dentin. The inner layer is called affected dentin and sits under the infected layer. Its consistency is harder, the collagen fibrils are not denatured, there is a mineral content loss and the amount of bacteria is reduced to $0.1 \%$, corresponding to $10^{5}$ bacteria per gram of dentin ${ }^{19}$. The objective of $\mathrm{MI}$ is to remove the infected dentin, and seal the cavity with an adhesive material, promoting an adequate environment for that inner demineralized dentin - affected - to heal ${ }^{17,25,26,30,37}$. The left bacteria can not reactivate the caries process if the obtained seal is adequate. There are some studies in the literature evaluating MI. Mertz-Fairhurst et al in 1998 published a 10year study evaluating MI and conventional treatment and the results were favorable towards $\mathrm{MI}^{22}$.

\section{ART - Steps}

ART technique consists basically in excavating caries tissue with hand excavators and filling the resulting cavity with glass ionomer cement. However, it is necessary to highlight that the restorative procedures are just a part of the treatment that includes oral hygiene instruction, preventive and restorative actions. The restorative sequence will be described because within this technique it differs from the conventional treatment, while the preventive procedures do not.

The patient is laid on a table and the clinical evaluation is performed. The cavities to be included in the ART treatment must follow the inclusion criteria. The inclusion criteria are: caries involving dentin, accessible caries and absence of fistula or pain. The exclusion criteria are: teeth with pulpal exposure, history of pain, presence of swelling or fistula history and lack of access to gain the carious tissue $e^{9,11}$.

The tooth or teeth to be restored are isolated with cotton wool rolls. The tooth surface to be treated is cleaned with a wet cotton wool pellet. The entrance of the lesion is widened with hatches if necessary, in order to start the excavation. If the smaller excavator can enter into the cavity, the excavation is started. The excavation is performed at the dentin-enamel junction (DEJ) before removing caries from the floor of the cavity, which is closest to the pulp. This sequence is performed to minimize sensitivity or discomfort during the excavation procedure ${ }^{9,11}$.

After excavation, the cavity is washed with water on a cotton pellet and checked for any soft remaining dentin. This verification is carried out with excavators or probes, seeking for soft tissue. The dentin-enamel junction needs to be thoroughly cleaned to prevent caries progression and to obtain a good seal. Provide pulpal protection only for very deep cavities applying calcium hydroxide cement to the deeper parts of the cavity ${ }^{9,11}$.

The cavity and the occlusal surface are cleaned rubbing cotton pellets containing weak conditioner, usually the cement liquid, used for mixing the material. The surfaces are rubbed for 10 to 15 seconds and then washed and dried with cotton pellets.

The glass ionomer cement should be mixed according to manufacturers' instructions and inserted into the cavity with the convex part of the excavator. The cavity should be slightly over filled and the material placed over pits and fissures. The operator should apply light pressure with a gloved and petroleum jelly coated finger on the top of the material during the initial setting. This procedure will promote a better GIC adaptation to the cavity walls and a smother surface which will facilitate the removal of the excess material.

The bite is checked using articulating paper and any premature contact is removed with the carver. Subsequently, a protection varnish is applied on the glass ionomer cement surface aiming to prevent gain or loss of water ${ }^{9,11}$. The patient is oriented not to eat or drink at least during the first hour after restoration placement $t^{9,11}$.

As ART approach is a preventive and restorative measure, all adjacent pit and fissures should be sealed at the same time of restoration. Teeth under risk of caries must also be sealed using the press finger technique. The sealant sequence is less time consuming than the restoration and includes cleaning dental surface, removing plaque and debris with an explorer, conditioning the enamel surface with a weak acid, inserting the material on the pit and fissures and pressing the material using a gloved petroleum jelly coated finger ${ }^{9,11}$. The instructions to the patients are the same as when restorative procedures are performed.

The technique is simple as reported in the literature, but this does not mean it could be perform in a neglected way. The sequence of the technique and the accuracy with dentists perform it are directly related to its success ${ }^{24}$.

Some clinical steps of the technique must be pointed out as crucial to achieve success: Lesion opening access, caries excavation, instrument sharpening, material handling and cavity restoration.

The opening access must be large enough to perform appropriate caries removal. The use of hatches aids widening the cavity entrance access. According to WHO manual, the minimal opening to reach dentinal caries is about $1 \mathrm{~mm}^{11}$. According to studies performed at Bauru Dental School (in press) the minimum cavity access opening to perform an adequate caries removal, after using hatches, including the dentin-enamel junction area is about $1.6 \mathrm{~mm}$. In this study the authors related limited movements for cleaning and hand fatigue in the group with opening of $1.4 \mathrm{~mm}$ or smaller.

The DEJ also receive special care in excavation because the access to it is limited by the enamel and this area represents a way for fast caries progression. The Bauru Dental School developed a kit containing a longer and thinner excavator intending to reach the DEJ area, specially in buccal and lingual walls of proximal boxes. The instruments are being commercialized in Brazil by SSWhite named ART Kit. This KIT has been used at Public dental service in Bauru, within an ART program and has been working properly. Because it is a thin and long instrument it must not be used 
to open cavities and to access small lesion, otherwise it can be damaged.

Another critical step is related to caries removal. It is necessary to know when excavation is adequate. Unfortunately, there is no objective parameter to guide excavation. Color and hardness of dentin are the most important to be considered. As dark dentin is not always related to the number of bacteria in a cavity and also darker dentin could be an arrested lesion, hardness becomes the most adequate criteria to determine when the excavation procedure is complete ${ }^{18}$. The left dentin should be referred as affected dentin instead of carious dentin, as this last one can misunderstand some dental care professionals.

The instrument / excavator sharpening is essential to obtain an adequate caries removal ${ }^{9,11,24}$. Each professional should observe and decide when to sharpen the instrument. An easy way to check if an instrument is sharpen is scratching on a plastic surface. If some slices come out, the instrument is sharpened, otherwise it is not.

After the excavation is completed, the cavity must remain clean and without saliva contamination in order to have the glass ionomer cement placed. If contamination occurs, the conditioning should be done again. A chair side assistant during this step aids to minimize the chances of contamination due to a faster procedure.

The material manipulation and insertion are the last procedures that require extra attention when performing the clinical procedures of the technique. Some training in extracted teeth is advised. Dentists must always follow the instructions given by the GIC manufactures' in order to achieve the best performance.

Due to the critical steps described before, some authors advise that training courses should be accomplished by those intending to perform the ART technique in order to achieve better results ${ }^{24}$. It was also observed at the Bauru Dental School that untrained operators achieved worse success rates than trained operators ${ }^{2,25}$.

\section{Research at PubMed in June/01/2004.}

Searching the literature related to ART at the date of the meeting, the author found 80 articles using the PubMed tool search (www.ncbi.nlm.nih.gov/PubMed) and selecting dental journal limits. From those 80 articles, 72 were related to the ART. Thirty-two discussed clinical results of the technique and only one was not written down in English. Nine articles reported ART in deciduous teeth, 17 in permanent and 5 in mixed dentition. Only 5 studies reported results using conventional glass ionomer cements while 26 report results using high viscous glass ionomer cements. When using conventional GIC, the results are lower than conventional treatment results, but with high viscous GIC, the results were similar and sometimes higher than conventional treatment. Some of these studies are presented in Table 1.

The author also searched in a Latin American search tool named LILACS (www.bireme.br). Sixteen articles were found, being six related to clinical research. The article summaries are found in Table 2.
As the objective of this paper was to perform a comparison among the results in literature with the results of studies carried out at Bauru Dental School, the table 3 was prepared.

\section{Family Health Progam - PSF (from portuguese "Programa de Saúde da Família")}

In Brazil the primary public health service is facing some changes. The information about prevention, in every health area, has been improved by a new program called "Programa de Saude da Familia” - PSF. In the PSF leaders from the community are trained to give information about general health for the population they live close by. Prevention is the main objective for diminishing diseases incidence and also for less medical appointments, allowing those who could not be prevented to be treated. This program endorses the ART technique in order to promote the restorative part of dental caries treatment faster. In this way more time is left for prevention. This fact is taking the Public Dental System in Brazil out of the restorative era, trying to be more focused in prevention and oral health promotion.

\section{CONCLUSION}

The ART approach is based on the minimal intervention in dentistry and represents a safety technique for treating dental caries disease. The knowledge about the technique as well as training courses should be taken for those intending to start using the technique in order to achieve better results. The preconception should be broken down and some subjective thoughts as leaving caries under restorations must be substituted by leaving affected dentin under restorations intending to standardize the procedures and to reduce neglected actions.

The demineralized tissue under ART restorations could heal if the treatment achieves an adequate seal. As a conventional treatment, the clinical procedure by itself is not able to stop the caries disease. The association of curative and preventive procedures is ideal.

\section{REFERENCES}

1- Bresciani E, Nogueira DA, Henostroza Quintans N, Barata TJE, Lauris JRP, Navarro MFL. Influência do isolamento absoluto sobre o sucesso do Tratamento Restaurador Atraumático (ART) em cavidades classe II, em dentes decíduos. Rev Fac Odontol Bauru. 2002,10:2317.

2- Bresciani E. Avaliação clínica de restaurações de cavidades classe I realizadas pela técnica do tratamento restaurador atraumático (ART) em comunidade de alto índice de cárie. Bauru; 2003. [Master Dissertation - Faculdade de Odontologia de Bauru da Universidade de São Paulo].

3- Cefaly DFG. Resistência adesiva à tração e avaliação clínica de cimentos de ionômero de vidro utilizados no ART. Bauru; 2003 [Thesis - Faculdade de Odontologia de Bauru, Universidade de São Paulo].

4- França MTC,.Bolinelli A, Seabra BGM, Navarro MFL. One year evaluation of ART technique [abstract]. J Dent Res. 1998;77:636. 
5- Frencken et al, Makoni F, Sithole F, Hackenitz F. Three-Year survival of one-surface restorations and glass-ionomer sealants in a school oral health programme in Zimbabwe. Caries Res. 1998,32:119-26.
6- Frencken JE, Holmgren C. Atraumatic Restorative Treatment for dental caries. Nijmegen: STI book b.v.;1999.

TABLE 1- Some of the studies found using the PUBMED search tool

\begin{tabular}{|c|c|c|c|c|c|c|}
\hline $\begin{array}{l}\text { Author/Year/ Place } \\
\text { of the study }\end{array}$ & GIC & Mean Age & $\mathrm{N}$ of Patients & $\begin{array}{l}\mathrm{N} \text { of Restorations/ } \\
\text { sealants }\end{array}$ & $\begin{array}{l}\text { Follow up } \\
\text { period }\end{array}$ & Success rate \\
\hline $\begin{array}{l}\text { Frencken } \\
\text { et al., } 1994^{10}\end{array}$ & $\begin{array}{l}\text { Chemfil } \\
\text { (Dentsply) }\end{array}$ & ------------- & $277-$ & 529 restorations 148 sealants & 1 year & $\begin{array}{l}\text { Deciduous } \\
1 \text { surface }=>79 \% \\
\text { Multisurface }=>55 \% \\
\text { Permanent } \\
1 \text { surface }=>93 \% \\
\text { Multisurface =>67\% } \\
\text { Sealant } \\
\text { Deciduous=>73\% } \\
\text { Permanents=>78\% }\end{array}$ \\
\hline $\begin{array}{l}\text { Frencken } \\
\text { et al.,1998 }\end{array}$ & $\begin{array}{l}\text { Chemfil } \\
\text { Superior } \\
\text { (Dentsply) }\end{array}$ & 13.9 & 569 & $\begin{array}{l}316 \text { single surface restorations } \\
511 \text { sealants }\end{array}$ & 1 and 3 years & $\begin{array}{l}\text { Restaurations: } \\
1 \text { year }=>93.4 \% \\
3 \text { years }=>85.3 \% \\
\text { Sealants } \\
1 \text { year: } \\
=>60.3 \% \text { - total retention } \\
=>13.4 \% \text {-partial retention } \\
=>\text { Carious lesions }-0.8 \% \\
3 \text { years: } \\
=>50.1 \% \text { total or partial retention }\end{array}$ \\
\hline $\begin{array}{l}\text { Phantumvanit } \\
\text { et al., } 1996^{31}\end{array}$ & $\begin{array}{l}\text { ChemFil } \\
\text { (Dentsply) }\end{array}$ & ----------- & 144 & 2411 surface restorations & 1,2 and 3 years & $\begin{array}{l}1 \text { year }=>93,0 \% \\
2 \text { years }=>83,0 \% \\
3 \text { years }=>71,0 \%\end{array}$ \\
\hline $\begin{array}{l}\text { Mallow } \\
\text { et al., } 1998^{21}\end{array}$ & Fuji II (GC) & $12-17$ & 53 & $\begin{array}{l}50 \text {-Class I } \\
33 \text {-Class V } \\
6 \text { Class- III }\end{array}$ & 1 and 3 years & $\begin{array}{l}\text { Class I- } \quad 87,5-60,9 \% \\
\text { Class III- } 40,0-25,0 \% \\
\text { Class V- } 71,4-66,7 \%\end{array}$ \\
\hline $\begin{array}{l}\text { Frencken } \\
\text { et al., } 1998^{5,8}\end{array}$ & Fuji IX (GC) & 14.1 & 208 & 297 & 1, 2 and 3 years & $\begin{array}{l}\text { Class I } \\
1 \text { year }=>98,6 \% \\
2 \text { years }=>93,8 \% \\
3 \text { years }=>88,35 \%\end{array}$ \\
\hline $\begin{array}{l}\text { Mickenautsch } \\
\text { et al., } 1999^{23}\end{array}$ & $\begin{array}{l}\text { Ketac- } \\
\text { Molar (KM) } \\
(3 \mathrm{M} \text { ESPE) } \\
\text { Fuji IX (F9) } \\
(\mathrm{GC})\end{array}$ & 10.5 & 113 & 163 & 1 year & $\begin{array}{l}\text { Class I } \\
\mathrm{F} 9-=>93,1 \% \\
\mathrm{KM}=>94,0 \%\end{array}$ \\
\hline $\begin{array}{l}\text { Holmgren } \\
\text { et al., } 2000^{14}\end{array}$ & $\begin{array}{l}\text { Ketac-Molar } \\
\text { (3M ESPE) }\end{array}$ & $12-13$ & 337 & $294 / 191$ & 1, 2 and 3 years & $\begin{array}{l}\text { Classe } I-\text { SMALL } \\
1 \text { year }=>99 \% \\
2 \text { years }=>96 \% \\
3 \text { years }=>92 \% \\
\text { EXTENSE } \\
1 \text { year }=>90 \% \\
2 \text { years }=>83 \% \\
3 \text { years }=>77 \%\end{array}$ \\
\hline $\begin{array}{l}\text { Lo; Holmgren, } \\
2001^{20}\end{array}$ & $\begin{array}{l}\text { Ketac-Molar } \\
\text { (3M ESPE) }\end{array}$ & 5.1 & & 170 & 12 and 30 months & $\begin{array}{l}12 \text { months }=> \\
\text { Class I - 91\% } \\
\text { Class II }-75 \% \\
\text { Class V- } 79 \% \\
30 \text { months=> } \\
\text { Class I - 79\% } \\
\text { Class V- 70\% } \\
\text { Class II }-51 \%\end{array}$ \\
\hline $\begin{array}{l}\text { Taifour } \\
\text { et al., } 2002^{35}\end{array}$ & $\begin{array}{l}\text { Fuji IX } \\
\text { (GC)-F9 } \\
\text { Ketac-Molar } \\
\text { (3M ESPE) } \\
\text { KM }\end{array}$ & $6-7$ & 835 & 482 & 3 years & $\begin{array}{l}86,1 \%-1 \text { surface restorations } \\
48,7 \%-2 \text { multisurface } \\
\text { restorations }\end{array}$ \\
\hline $\begin{array}{l}\text { Souza EM } \\
\text { et al } 2003^{33}\end{array}$ & $\begin{array}{l}\text { Fuji IX and } \\
\text { Fuji Plus }\end{array}$ & $7-12$ & 208 & 473 & 8 months & $\begin{array}{l}\text { FIX }-86.2 \% \text { occlusal } \\
\text { F Plus - } 88.4 \% \text { occlusal } \\
86.7 \% \text { - approximal }\end{array}$ \\
\hline $\begin{array}{l}\text { Wang L et } \\
\text { al } 2004^{38}\end{array}$ & Ketac Molar & $7-12$ & 118 & 150 & 3 years & $\begin{array}{l}\text { Success } 21 \% \\
94.7 \% \text { retained teeth }\end{array}$ \\
\hline
\end{tabular}


7- Frencken JE, Makoni E, Sithole WD. ART restorations and glassionomer sealants in Zimbabwe; survival after 3 years. Community Dent Oral Epidemiol. 1998,26:372-81.

8- Frencken JE, Makoni E, Sithole WD. Atraumatic restorative treatment and glass-ionomer sealants in a school oral health programme in Zimbabwe: Evaluation after 1 year. Caries Res. 1996,30:28-33.
9- Frencken JE, Pilot T, Songpaisan Y, Phantumvanit P. Atraumatic restorative treatment (ART): rationale, technique, and development. J Public Health Dent. 1996,56:135-40.

10- Frencken JE, Songpaisan Y, Phantumvanit P, Pilot T. Atraumatic restorative treatment (ART) technique: evaluation after one year. Int Dent J. 1994;44:460-4.

TABLE 2- Clinical studies searched at LILACS at June $1^{\text {st }}, 2004$

\begin{tabular}{|c|c|c|c|c|c|c|}
\hline $\begin{array}{l}\text { Author/Year/ Place } \\
\text { of the study }\end{array}$ & GIC & Mean Age & $\mathrm{N}$ of Patients & $\begin{array}{l}\mathrm{N} \text { of Restorations/ } \\
\text { sealants }\end{array}$ & $\begin{array}{l}\text { Follow up } \\
\text { period }\end{array}$ & Success rate \\
\hline $\begin{array}{l}\text { Neves AA } \\
\text { et al } 1999^{28}\end{array}$ & & & & & & $\begin{array}{l}80 \% \text { - deciduous teeth } \\
64 \% \text { - permanent teeth }\end{array}$ \\
\hline $\begin{array}{l}\text { Souza MIC } \\
\text { et al } 1999^{34}\end{array}$ & Fuji IX & $6-10$ & 11 & & 1 month & $\begin{array}{l}\text { Reduction in Lactobacilli } \\
\text { counts }\end{array}$ \\
\hline $\begin{array}{l}\text { Oliveira } \\
\text { LMC 200029 }\end{array}$ & Vidrion $\mathrm{R}$ & 8.3 & 50 & & 1 year & $\begin{array}{l}\text { Permanent teeth }-50 \% \\
\text { Deciduous teeth }-39 \%\end{array}$ \\
\hline $\begin{array}{l}\text { Bresciani } \\
\text { et al., 2002- } \\
\text { Brazil }^{1}\end{array}$ & $\begin{array}{l}\text { Ketac-Molar } \\
\text { (3M ESPE) } \\
\text { KM }\end{array}$ & 4-6 & 38 & 59 & 6 months & $\begin{array}{l}\text { Class II } \\
\text { Rubber dam- } 74.35 \% \\
\text { Cotton wools - } 66.66 \%\end{array}$ \\
\hline $\begin{array}{l}\text { Bresciani 2003- } \\
\text { Brazil }^{2}\end{array}$ & $\begin{array}{l}\text { Ketac-Molar } \\
\text { (3M ESPE) }\end{array}$ & $7-12$ & 96 & 155 & 6 months, 1 e 2 years & $\begin{array}{l}\text { Class I } \\
6 \text { months- } 97.3 \% \\
1 \text { year- } 93.7 \% \\
2 \text { years- } 89.6 \%\end{array}$ \\
\hline $\begin{array}{l}\text { Cefaly, 2003- } \\
\text { Brazil }^{3}\end{array}$ & $\begin{array}{l}\text { Ketac-Molar } \\
(3 \mathrm{M} \text { ESPE) } \\
(\mathrm{KM}) \\
\text { Fuji VII (F8) } \\
\text { (GC) }\end{array}$ & $9-16$ & 30 & 60 & 6 months and 1 year & $\begin{array}{l}\text { Multisurface restorations } \\
\text { KM and F8 } \\
6 \text { months- } 98.3 \% \\
1 \text { year- } 96.6 \%\end{array}$ \\
\hline
\end{tabular}

TABLE 3- Clinical Studies with ART performed at Bauru Dental School

\begin{tabular}{|c|c|c|c|c|c|c|}
\hline $\begin{array}{l}\text { Author/Year/ Place } \\
\text { of the study }\end{array}$ & GIC & Mean Age & $\mathrm{N}$ of Patients & $\begin{array}{l}\mathrm{N} \text { of Restorations/ } \\
\text { sealants }\end{array}$ & $\begin{array}{l}\text { Follow up } \\
\text { period }\end{array}$ & Success rate \\
\hline $\begin{array}{l}\text { França et al, } \\
\text { 1998-Brazil }{ }^{4}\end{array}$ & Fuji IX (GC) & $4-6$ & 137 & 320 & 1 year & $\begin{array}{l}\text { Class I-75.3\% } \\
\text { Class II-39.1\% } \\
\text { Class III-72.9\% } \\
\text { Class IV-55.6\% } \\
\text { Class V-90\% }\end{array}$ \\
\hline $\begin{array}{l}\text { Rodrigues et al., } \\
\text { 1998- Brazil }{ }^{32}\end{array}$ & $\begin{array}{l}\text { Fuji IX (GC)- } \\
\text { F9 } \\
\text { Fuji Plus } \\
\text { (GC)-FP }\end{array}$ & $3-6$ & ---------- & 281 & 6 months & $\begin{array}{l}\text { Fuji IX } \\
\text { Class I-71.7\% } \\
\text { Class II-29.6\% } \\
\text { Fuji Plus } \\
\text { Class II-92.9\% }\end{array}$ \\
\hline $\begin{array}{l}\text { Terada } \\
\text { et al., } 1998 \text { - } \\
\text { Brazilib }^{36}\end{array}$ & $\begin{array}{l}\text { Fuji IX (GC)- } \\
\text { F9 } \\
\text { Fuji Plus } \\
\text { (GC)-FP }\end{array}$ & 3-7 & 119 & 525 & 6 months & $\begin{array}{l}\text { Fuji IX } \\
\text { Class I-89.6\% } \\
\text { Fuji Plus } \\
\text { Class I-90.9\% } \\
\text { Class II-78.4\%\% }\end{array}$ \\
\hline $\begin{array}{l}\text { Bresciani } \\
\text { et al., 2002- } \\
\text { Brazil }^{1}\end{array}$ & $\begin{array}{l}\text { Ketac-Molar } \\
\text { (3M ESPE) } \\
\text { KM }\end{array}$ & $4-6$ & 38 & 59 & 6 months & $\begin{array}{l}\text { Class II } \\
\text { Rubber dam- } 74.35 \% \\
\text { Cotton wools }-66.66 \%\end{array}$ \\
\hline $\begin{array}{l}\text { Bresciani 2003- } \\
\text { Brazil }^{2}\end{array}$ & $\begin{array}{l}\text { Ketac-Molar } \\
\text { (3M ESPE) }\end{array}$ & $7-12$ & 96 & 155 & 6 months, 1 e 2 years & $\begin{array}{l}\text { Class I } \\
6 \text { months- } 97.3 \% \\
1 \text { year- } 93.7 \% \\
2 \text { years- } 89.6 \%\end{array}$ \\
\hline $\begin{array}{l}\text { Cefaly, 2003- } \\
\text { Brazil }^{3}\end{array}$ & $\begin{array}{l}\text { Ketac-Molar } \\
(\mathrm{KM}) \\
(3 \mathrm{M} \text { ESPE) } \\
\text { Fuji VII (F8) } \\
(\mathrm{GC})\end{array}$ & $9-16$ & 30 & 60 & 6 months and 1 year & $\begin{array}{l}\text { Multisurface restorations } \\
\text { KM and F8 } \\
6 \text { months- } 98.3 \% \\
1 \text { year- } 96.6 \%\end{array}$ \\
\hline
\end{tabular}


11- Frencken JE, van Amerogen E, Phantumvanit P, Songpaisan Y, Pilot T. Manual for the Atraumatic Restorative Treatment approach to control dental caries. WHO Collaborating Centre for Oral Health Services Research. $3^{\text {rd }}$ ed. Groningen; 1997.

12- Fusayama T. Two layers of carious dentin: diagnosis and treatment. Oper Dent. 1979,:63-7.

13- Guggenberger R, May R, Stefan KP. New trends in glass-ionomer chemistry. Biomaterials. 1998;19:479-83.

14- Holmgren CJ, Lo EC, Hu D, Wan H. ART restorations and sealants placed in Chinese school children - results after three years. Community Dent Oral Epidemiol. 2000,28:314-20.

15- Holmgren CJ, Pilot T. Discussion from the symposium "minima intervention techniques for caries”. J Public Health. 1996,56:161-5.

16- Holmgren CJ. Discussion from the 1998 IADR symposium: the state of ART (atraumatic restorative treatment) - a scientific perspective. Community Dent Oral Epidemiol.1999,27:454-60.

17- Ismail AI. Reactor paper: minimal intervention techniques for dental caries. J Public Health Dent. 1996;56:155-60.

18- Kidd EAM, Ricketts DNJ, Beighton D. Criteria for caries remova at the enamel-dentine junction: a clinical and microbiological study. Brit Dent J. 1996;180:287-91.

19- Kubori Y, Ohgushi K, Fusayama T. Collagen biochemistry of the two layer of carious dentin. J Dent Res. 1977;56:1233-7.

20- Lo EMC, Holmgren CJ. Provision of atraumatic restorative treatment (ART) restorations to Chinese pre-school children - a 30month evaluation. Int J Paediatr Dent. 2001;11:3-10.

21- Mallow PK, Durward CS, Klaipo M. Restoration of permanent teeth in young rural children in Cambodia using the atraumatic restorative treatment (ART) technique and Fuji II glass ionomer cement. Int J Paediatr Dent. 1998;8:35-40.

22- Mertz-Fairhurst EJ, Curtis JW, Ergle JW, Rueggeberg FA, Adair SM. Ultraconservative and cariostatic sealed restorations: results at year 10. J Am Dent Assoc. 1998;129:55-66.

23- Mickenautsch S, Rudolph MJ, Ogunbodede EO, Frencken JE. The impact of the ART approach on the treatment profile in a mobile dental system (MDS) in South Africa. Int Dent J. 1999;3:132-

24- Mickenautsch S, Rudolph MJ. Undergraduate training in the atraumatic restorative treatment (ART) approach - an activity report. SADJ 2002;57:355-57.

25- Mount GJ, Ngo H. Minimal intervention: a new concept for operative dentistry. Quintessence Int. 2000;31:527-33.

26- Mount GJ, Ngo H. Minimal intervention: advanced lesions. Quintessence Int. 2000;31:621-9.

27- Navarro MFL, Cefaly DFG, Tapety CMC Lauris JRP. Long-term evaluation of ART in Class III and V restorations [abstract]. J Dent Res. 2004; CD-Rom

28- Neves AA, Souza IPR. Avaliação do tratamento restaurador atraumático em crianças infectadas pelo HIV. Rev Bras Odontol. 1999;56:2-6.

29- Oliveira LMC. Avaliaçäo de um programa de tratamento restaurador atraumático em crianças institucionalizadas, Rio de Janeiro; 2000. [Thesis - Faculdade de Odontologia da Universidade Federal do Rio de Janeiro].
30- Peters MC, McLean ME. Minimal intervention and concepts for minimally invasive cavity preparations. J Adhes Dent. 2001;3:7-16.

31- Phantumvanit P, Songpaisan Y, Pilot T, Frencken JE. Atraumatic restorative treatment (ART): a three-year community field trial in Thailand - survival of one-surface restorations in the permanent dentition. J Public Health Dent. 1996;56:141-5.

32- Rodrigues CC, Bonelli A, Seabra BGM, França MTC, Navarro MFL. Six months evaluation of ART technique using Fuji IX and Fuji Plus [abstract]. J Dent Res. 1998;77:636

33- Souza EM, Cefaly DFG, Terada RSS, Rodrigues CCM, Navarro MFL. Clinical evaluation of the ART technique using high density and resin-modified glass ionomer cements. Oral Health Prev Dent. 2003;1:201-7.

34- Souza MIC, Medeiros UV, Santos PKG. Avaliaçäo clínica da alteraçäo da microflora oral por meio da utilizaçäo do tratamento restaurador atraumático. Rev Bras Odontol. 1999,56:34-7.

35- Taifour D, Frencken JE, Beiruti N, van't Hof MA, Truin GJ. Effectiveness if glass-ionomer (ART) and amalgam restorations in the deciduous dentition: results after 3 years. Caries Res. 2002,6:43744.

36- Terada RSS, Souza EM, Rodrigues CC, Seabra BG, Navarro MFL. Clinical evaluation of the Atraumatic restorative treatment (ART) in primary teeth [abstract]. J Dent Res. 1998;77:965.

37- Tyas MJ, Anusavice KJ, Frencken JE, Mount GJ. Minimal intervention dentistry - a review. Int Dent J. 2000;50:1-12.

38- Wang L, Lopes LG, Bresciani E, Lauris JR, Mondelli RFL, Navarro MFL. Evaluation of Class I ART restorations in Brazilian schoolchildren: three-year results. Spec Care Dentist. 2004;24:2833.

39- WHO/28 - 7 April 1994. Revolutionary new procedure for treating dental caries. Disponível na Internet: http://www.who.int/archieves/ inf-pr-1994/pr94-28.html.

40- WHO: Oral Health Disponível na Internet: Site http:// www.who.int/aboutwho/en/promoting/oral.html. 